\title{
Was die Optrede van die Konsulentsgemeente Pretoria in 1885 "Kerkskeurend?"
}

\author{
A D PONT
}

\section{Inleidende Opmerkings}

Die geskiedenis van die Afrikaner en sy kerk in die gebied noord van die Vaalrivier is deel van die wordingsgeskiedenis van die Afrikanervolk of nasie. Daardie wordingsgeskiedenis word, uit die aard van die saak, grotendeels bepaal deur die staatkundige verwikkelinge hier in Suider-Afrika. As 'n oomblik veralgemeen mag word, dan kan gesê word dat die Afrikanervolk gevorm is enersyds deur sy stryd teen die opdringende imperialisme van Engeland en aan die ander kant deur sy afgrensing teen die barbarisme van die nie-blanke heidendom in Suider-Afrika. Dit is veral waar ten opsigte van die Voortrekkers en hulle nasate wat die leë binneland van die Oorvaalse gebied in die dekades van dertig en veertig kom bewoon en vir die beskawing oopgestel het. Hoewel hierdie Voortrekkers aanvanklik nié 'n volk genoem kan word nie maar eerder familie- en gebiedsgroepe gevorm het, ${ }^{1}$ het die druk van die nie-blanke barbarisme en die opdringende Engelse imperialisme die nasionale samebinding voortdurend gestimuleer. Die Afrikaner-nasionalisme en volkswording in die Oorvaalse is veral gestimuleer deur die annekasie van die $Z$ A Republiek in 1877 en die daaropvolgende suksesvolle vryheidsoorlog van 1880-1881. Die veldslae van Bronkhorstspruit, Ingogo en veral Majuba waar die Engelse troepemagte telkens vernietigend verslaan is, het ' $n$ sterk nasionale gevoel en nuwe besef van eiewaarde onder die Afrikaner van die $Z$ A Republiek én die hele Afrikaner-gemeenskap van Suider-Afrika laat posvat. $^{2}$

$\mathrm{Na}$ die oorlog van $1880-1881$ is deur die leidinggewende staatsmanne van die $Z$ A Republiek getrag om die nuutgevonde nasionale selfbewussyn en eenheidsgevoel te behou en te stimuleer. In hierdie situasie is die gedagte van 'n vereniging van die drie Afrikaanse kerke gepropageer omdat geoordeel is dat die bestaan van drie kerke middelpuntvliedend kan funksioneer. ${ }^{3}$

Die staatkundig-kulturele eenheidsgevoel wat so na die drie Afrikaanse kerke oorgedra is, het in die kerke self 'n sekere klankbodem gevind want reeds in 1879 is die moontlikheid van 'n kerklike vereniging in die Algemene Kerkvergadering van die Ned Hervormde Kerk positief gewaardeer. ${ }^{4}$ Dit is egter wel duidelik dat die kerklike eenheidstrewe wat gelei het tot die sogenaamde 
Kerkvereniging van 1885 'n sterker staatkundig-kulturele impuls as 'n kerklike-godsdienstige aandrang gehad het. Dit is dan ook opvallend dat daar relatief min kerklike en leerstellig-godsdienstige voorbereiding en algemene diskussie binne die kerke self aan die vereniging voorafgegaan het. $^{5}$

Nadat geblyk het dat die Gereformeerde Kerk nie aan 'n voorgestelde vereniging sou deelneem $n^{6}{ }^{6}$ het die Ned Hervormde en die Ned Gereformeerde kerke oorgegaan tot onderhandelings om 'n basis vir vereniging te vind. ${ }^{7}$

\section{Die Kerkvereniging}

Op 31 Oktober 1882 het 'n kommissie van die Ned Hervormde Kerk 'n soortgelyke kommissie van die Ned Gereformeerde Kerk in die ou Hervormde kerkgebou op Kerkplein in Pretoria ontmoet. Die besprekings tydens die vergaderings van hierdie kommissies het aangetoon dat daar nog 'n duidelike kloof tussen die uitgangspunte én standpunte van die twee kerke was. ${ }^{8}$ Veral op die kerklikgodsdienstige vlak het, ondanks die formele ooreenstemming oor die leer van die kerk, geblyk dat die politiek-staatkundige of anders gesê, die lewensbeskoulike verskille nie so maklik oorbrug sou word nie. Die noue verbondenheid wat die Ned Gereformeerde Kerk gevoel en gehandhaaf het met die Ned Gereformeerde Kerk in die Engelsgedomineerde Kaapkolonie was vir die Ned Hervormde Kerk wat hom geïdentifiseer het met die Afrikaans-nasionale selfbewussyn, nie so maklik om te aanvaar nie. ${ }^{9}$ Die vraag waarom die Ned Hervormde Kerk se kommissie én die daaropvolgende Algemene Kerkvergadering die verenigingsvoorstelle aanvaar het, is al meer male gestel. Die rede vir dié aanvaarding, wat die prysgawe beteken het van 'n aantal sake wat vir die Ned Hervormde Kerk van groot gewig was, moet waarskynlik gesoek word in 'n opregte begeerte by die Ned Hervormde Kerk om die staatkundig-kulturele ideaal, wat die aanleiding tot die vereniging gegee het, nie te skaad nie. Die merkwaardige in die hele onderhandelinge tussen die twee kommissies en die daaropvolgende onderhandelinge tussen die twee Algemene Vergaderings was nie alleen dat die Ned Hervormde Kerk baie oppervlakkig gedink en gehandel het nie, ${ }^{10}$ maar óók dat die kerklik-godsdienstige én die staatkundig-kulturele verskille nooit werklik aangeroer en uitgepraat is nie. Die feit dat die Ned Hervormde Kerk se predikante op daardie stadium merendeels produkte van die Stellenbosse Kweekskool was en dus ' $n$ ander staatkundig-kulturele standpunt gehuldig het as die lidmate en kerkraadslede het waarskynlik hierin 'n rol gespeel. Die merkwaardige is dan ook dat, afgesien van ds G W Smits en ds CW du Toit, al die diensdoende predikante van die Ned Hervormde Kerk van 1885 sondermeer met die vereniging saamgegaan het. Die mislukking van 
die Kerkvereniging en die herstel van die Ned Hervormde Kerk was grotendeels te danke aan die kerkraadslede en lidmate van die kerk wat in hierdie saak ' $n$ baie beter aanvoeling en insig as die geleerde predikante en kerklike leiers geopenbaar het. Selfstandige en beginselvaste denke, was hier vir die kerk van groter waarde as slaafse navolging en die konformering aan die opvattings van die meerderheid.

Die taak van die twee kerklike kommissies om 'n basis vir die vereniging uit te werk, het danksy die toegeeflikheid van die Hervormde afvaardiging besonder goed gevlot. Reeds op 8 November 1882 is die werk van die twee kommissies afgehandel en is hulle rapport na die Algemene Vergaderings van die twee kerke verwys. ${ }^{10}$

Die bespreking van die Kommissierapport op die Algemene Vergadering van die Ned Hervormde Kerk was maar kort. Ds J C de Vries het voorgestel: ${ }^{11}$

"De oorlog had eendracht bewerkt; men had wonderen gedaan, men had niet gevraagd: tot welke kerk behoord gij? Maar men stond als mannen naast elkander. Het was een grootsche overwinning op politiek gebied, maar de overwinning in de Kerk kon men nog als grooter beschouwen. Hij had nu een voorstel van den volgenden inhoud: dat het werk van de Commissie ter vereeniging door deze vergadering goedgekeurd en aangenomen worde bij acclamatie, zonder discussie."

Hierdie voorstel is met net twee teenstemme aangeneem en hieruit word tog weer duidelik dat die nuutgevonde politieke selfbewussyn van die Transvalers ' $n$ baie sterk stimulans tot kerkvereniging was. ${ }^{12}$ Nie die kerklik-godsdienstige argument nie maar die staatkundigkulturele argument word hiér die deurslaggewende. Geleidelik egter is daar meer aandag aan die verenigingsvoorstelle gegee veral nadat die Algemene Vergadering van die Ned Gereformeerde Kerk ook daaroor gehandel het. Veral die kwessie van die legitimasie van die predikante van die nuwe, verenigde kerk het, wat die Ned Hervormde Kerk betref, byna die vereniging laat afspring. ${ }^{13}$ Hier en daar kon die argument gehoor word dat die vereniging begin lyk na 'n "oorgawe" van die Ned Hervormde Kerk aan die Ned Gereformeerde Kerk en as die verenigingsvoorstelle sorgvuldig nagegaan word dan is dit duidelik dat dit presies is wat van Ned Gereformeerde-kant met die vereniging beoog is. ${ }^{14}$

Nadat die onderlinge verskille op die Algemene vergaderings van 1884 en 1885 verder uitgestryk is, ${ }^{15}$ is alles in werking gestel om die vereniging nog gedurende 1885 te laat plaasvind. Oral waar moontlik en nodig, het volgens die verenigingsbesluit, die kerkrade van die Ned Hervormde en Ned Gereformeerde gemeentes saamgekom, één liggaam gevorm en afgevaardigdes gekies na die eerste Algemene 
Kerkvergadering van die verenigde kerk wat op 7 Desember 1885 te Pretoria gekonstitueer het. Hierdie prosedure is vasgestel volgens artikel XI van die besluite van die tweede verenigingskommissie wat gedurende 1885 byeengekom het. ${ }^{16}$ Artikel XI het soos volg gelui. ${ }^{17}$

"Bij de gemeente welke een leraar heeft, gehad heeft, of beroepen heeft, voege zich de gemeente die nog geen leraar heeft, gehad heeft of beroepen heeft. De oude en dienstdoende Kerkeraadsleden aan beide zijden worden als zoodanig erkend. Tot volvoering worden dag en plaats vooraf bepaald door de beide Kerkeraden. De Kerkeraad der zich aansluitende gemeente, overhandigt boeken, documenten, eigendommen en vast goed (welke laatste tot op vaststelling van den naam der Kerk nog op de respectieve namen blijven). Van den dag der ineensmelting, zullen de twee dienstdoende Kerkeraden den Kerkeraad der ineengesmoltene gemeente uitmaken. Aan beide Kerkeraadsleden en gemeenteleden zal vrij staan, indien zij bezwaren hebben, om bij den leraar der gemeente, waarbij zij zich aansluiten, de Sacramenten te ontvangen, te gaan naar een Evangeliedienaar, om bediening in hunne geestelijke voorregten. Deze vergunning blijft totdat de diensdoende leeraar wegvalt. Elk Kerkeraadslid of gemeentelid dat van deze vergunning gebruik wil maken, zal binnen drie maanden van af den dag der ineensmelting van zijn voornemen moeten kennis geven."

Uit hierdie artikel en ook artikel XIII waar oor die gemeentes te Potchefstroom gehandel is, word dit duidelik dat dit hier uitsluitlik gaan om die vereniging van alle de facto bestaande Ned Hervormde en Ned Gereformeerde gemeentes.

Nadat hierdie ineensmelting gedurende die tweede helfte van 1885 plaasgevind het, het die eerste Algemene Vergadering van die nuwe, verenigde kerk op 7 Desember 1885 byeengekom. Daarmee het die Kerkvereniging dan tot stand gekom maar dit sou geen blywende vereniging wees nie.

\section{Die Konsulentsgemeente Pretoria}

Die Konsulentsgemeente van Pretoria wat met die eerste Algemene Vergadering van die verenigde kerk in die kalklig gekom het, was 'n merkwaardige verskynsel binne die organisatoriese struktuur van die Ned Hervormde Kerk. Sonder om hier op al die besonderhede in te gaan, kan slegs gestel word dat die gemeente in November 1869 deur die Algemene Kerkvergadering gestig is. Hierdie gemeente wat dieselfde grense as die gemeente Pretoria gehad het, het ontstaan vanweë 'n onenigheid rondom die persoon van ds A J Begemann. Omdat in die staatskerk net één predikantstandplaas per distrik deur 
die owerheid bekostig is, is die gemeente deur ds G W Smits as konsulent bearbei. Geleidelik het Witfontein, die woonplaas van ouderling M J Prinsloo, die middelpunt van die gemeente geword. ${ }^{18}$

Hoewel die gemeente ontstaan het vanweë die bevoegde vergadering van die ampte se onvermoë of onwilligheid om 'n ànder verkeerdheid reg te stel, het die gemeente ' $n$ de facto gemeente van die Ned Hervormde Kerk geword en het as sodanig al die regte én voorregte van enige ander gemeente in die Kerk gehad. ${ }^{19}$ Met die kerkvereniging en vóór die eerste Algemene Vergadering het ds $\mathrm{N} \mathrm{J}$ van Warmelo 'n poging aangewend om die konsulentsgemeente te oorreed om met die Ned Hervormde Gemeente Pretoria, wat deur ds H S Bosman bedien is, te verenig. Op dié manier wou Van Warmelo die kerkordelike fout wat in 1869 gemaak is, herstel maar die Konsulentsgemeente het nié hierop ingegaan nie. ${ }^{20}$ Inmiddels het die Ned Gereformeerde gemeente Pretoria wat sy sentrum aan die Elandsrivier gehad het, wél met die Ned Hervormde gemeente Pretoria, kragtens die reedsgenoemde Artikel XI, verenig.

Met die konstituering van die Algemene Vergadering van die nuwe verenigde kerk het die voorsitter, ds $H$ L Neethling van Utrecht nié die naam van die Konsulentsgemeente van Pretoria gelees nie sodat dié afgevaardigdes nie aan die konstituering kon deelneem nie. Daarmee het die voorsitter die sittingsreg van die afgevaardigdes en die bestaansreg van die Konsulentsgemeente Pretoria in die organisatoriese bedeling van die verenigde kerk ontken. ${ }^{21}$ Nadat die vergadering wettig gekonstitueer is, is oor die posisie van die Konsulentsgemeente gehandel en is besluit: ${ }^{22}$

"Deze vergadering betreurt het, dat de Consulentsgemeente van Pretoria nog niet vereenigd is met die gemeente van Pretoria, en verzoekt haar dringend om voor de volgende Algemene Vergadering de ineensmelting volgens Artikel 11 te doen plaats vinden."

In die daaropvolgende korrespondensie met die Konsulentsgemeente, het die kerkraad van hierdie selfstandige gemeente op 13 Februarie 1886 besluit:23

“Overwegende dat door de Hoog Eerw Algemeene Kerkvergadering der Ned Hervormde of Gereformeerde Gemeente in de ZAR, zitting houdende te Pretoria 7 December 1885, de Consulentsgemeente van Pretoria niet op de rij der gemeenten is geplaatst;

Overwegende, dat er bij die gelegenheid ook geene afgevaardigden door den Hoog Eerw Voorzitter zijn opgeroepen; Overwegende, dat dientengevolge ook geene afgevaardigden hebben kunnen zitting nemen, al zouden zij ook tegenwoordig zijn geweest; 
Overwegende, dat het besluit der Hoog Eerw Algemene Kerkvergadering dato X Pretoria 7 December 1885 ten eenemale in strijd is met een schrijven van den Voorzitter en Scriba der Commissie Algemene Kerkvergadering, dato Pretoria 15 September 1885, uit welk schrijven het blijkt als het gevoelen van de Hoog Eerw Commissie dat de Consulentsgemeente niet valt onder Artikel 11 der Commissiebesluiten Januarij 1885; . . .

Zoo besluit de Kerkeraad heden avond eene bijeenkomst te houden ten einde het gevoelen der Gemeenteleden te weten wat hun te doen staat in deze met betrekking het besluit der Hoog Eerw Algemene Kerkvergadering dez Ned Hervormde of Gereformeerde Gemeente, ..."

Die gemeentevergadering is daardie selfde aand onder voorsitterskap van kommandant Salomon Prinsloo gehou en daar is toe besluit: ${ }^{24}$

“De vergadering dezer gemeente ... Maakt geene objectie omtrent het niet opnemen dezer Gemeente in de rij der Gemeenten van de Ned Hervormde of Gereformeerde Kerk. Gevoelt ons integendeel tevreden te blijven hetgeen wij was en nu nog ben, namelijk Ned Hervormde. Deze vergadering verklaart verder dat $\mathrm{zij}$ onder geene omstandigheden zullen aansluiten bij die Kerkgenootschap, waardoor inbreuk zal kunnen worden gemaakt op de naam en regten van de Ned Hervormde Kerk, zooals dezelve zijn neergelegd in artikel 20 onzer Grondwet . . ."

Daarmee was die saak wat die Konsulentsgemeente betref, gefinaliseer en afgehandel.

Die Algemene Vergadering van die nuwe, verenigde kerk moes besef het dat die optrede en besluite van Desember 1885 ernstige probleme kon skep en het daarop in 1886 pogings aangewend om die Konsulentsgemeente oor te haal om tog tot die vereniging toe te tree. Die voorwaarde was egter dat die Konsulentsgemeente met die gemeente van ds H S Bosman moes saamsmelt want die besluit van Desember 1885 is nooit herroep nie. Solank daardie voorwaarde bly staan het, was 'n samesmelting ook onmoontlik want in die Konsulentsgemeente, wat uit troue vaderlanders bestaan het, was daar ernstige bedenkinge teen ds $\mathrm{H}$ S Bosman veral vanweë sy pro-Engelse houding in die jare 1877-1881. Die Konsulentsgemeente het geen lus gehad om hom aan ds Bosman se staatkundig-kulturele leiding te onderwerp nie. Die gemoedstoestand in die Konsulentsgemeente kan gepeil word uit 'n skrywe van $W$ Louis, die korrespondent van die kerkraad wat in 1887 na Nederland skrywe in verband met die beroep van 'n Nederlandse predikant vir die Konsulentsgemeente en dan sê::25 
"Mocht toch de a s predikant van de Hervormde Kerk maar een man zijn die bij een vroom gemoed, alle lust heeft om te staan tegenover die Kaapsche partij, wier ernstig streven is om ons zoo spoedig mogelijk geestelij Engelsch te maken ..."

Dit is, terloops, die ironie van die geskiedenis dat die Kerkvereniging wat grotendeels vanuit 'n staatkundig-kulturele oorweging geloods is, juis vanweë staatkundig-kulturele oorwegings ook weer doodgeloop het. Miskien sou die geskiedenis anders geloop het as die kerklik-godsdienstige motief die bepalende was. Die tragiek is egter dat die staatkundig-kulturele oorwegings dikwels in die Afrikaanse kerke 'n belangriker rol gespeel het as die suiwer kerklik-godsdienstige argument.

In 1888 het die Algemene Vergadering van die verenigde kerk finaal afskeid geneem van sy pogings om sy besluit van 1885 deur te voer toe die Vergadering dit betreur dat: ${ }^{26}$

“.. hare commissie door de aangenomen houding van de Kerkeraad van Witfontein verhinderd is om de door de vergadering zoo zeer gewenschte toenadering te bewerken, en drukt bij deze als haar gevoelen uit dat zij nog gedurig bereid is om die broeders in de Vereenigde Kerk op te nemen."

\section{Die oorsake van die "skeuring"}

Dit is kortliks die historiese feite van die 1885-situasie toe die Konsulentsgemeente van Pretoria nie deel geword het van die nuwe, verenigde kerk wat op 7 Desember 1885 te Pretoria opgerig is nie. Die vraag wat nou beantwoord moet word, is: Waar lê die oorsaak van hierdie situasie? Dit is natuurlik 'n oop vraag of hier sprake moet wees van "sondige verskeurdheid" want dit impliseer dat daar 'n ernstige leerstellinge vergryp was. Dit is wel duidelik dat hier nie juis leerstellinge kwessies aan die orde was nie maar veel eerder lewensbeskoulike en dan veral kerkregtelike kwessies. Ter wille van die duidelikheid moet hier die kerkregtelike situasie in die eerste plek besien word. Dan moet allereers gestel word dat die Konsulentsgemeente van Pretoria vanaf 1869 de facto én de iure 'n volwaardige gemeente van die Ned Hervormde Kerk was. Hierdie gemeente se kerkraad het deelgeneem an al die Hervormde Algemene Kerkvergaderings tot 1885. Dit is wel duidelik dat vanaf 1882 die Kerkraadsafgevaardigdes sterk bedenkings teen die voorgenome kerkvereniging gehad het maar dit het die kerkraad nie daarvan weerhou om aan al die vergaderings deel te neem nie. Wanneer uiteindelik in 1885 oorgegaan word tot die vereniging van die kerkraadsvergaderings, volgens die Tweede Verenigingskommissie van 1885 se aanvaarde verslag, dan ontstaan daar'n probleem ten opsigte van die Konsulentsgemeente. Dié probleem ontstaan 
vanweẽ die feit dat daar in die distrik Pretoria twee Hervormde gemeentes en net een Ned Gereformeerde gemeentetjie bestaan. Die posisie van die Ned Gereformeerde gemeentetjie was duidelik. Kragtens artikel XI van die ooreenkoms moes dié gemeente se kerkraad saamsmelt met die Hervormde gemeente wat 'n diensdoende predikant het. Daarom het die Ned Gereformeerde kerkraad ook met die kerkraad van die Hervormde gemeente Pretoria, waar ds H S Bosman gestaan het, saamgesmelt. Die posisie van die Konsulentsgemeente was onduidelik.

Daarop het die Konsulentsgemeente soos dit reg en behoorlik is, die Kommissie van die Algemene Kerkvergadering om advies en om 'n uitleg van artikel XI gevra. Die Kommissie het beslis dat die bepaling van artikel XI nie van toepassing was op die Konsulentsgemeente nie. Dit was ook 'n volkome korrekte uitleg van die betrokke artikel.

Die enigste liggaam wat hierdie beslissing van die Kommissie sou kon wysig, was die Algemene Vergadering van die Ned Hervormde Kerk self. Omdat dié vergadering nie meer in sitting gekom het nie, het die beslissing van die Kommissie as gesaghebbend bly bestaan.

By die samekoms van die eerste Algemene Vergadering van die verenigde kerk op 7 Desember 1885 het ds H L Neethling as hy regmatig wou optree, géén ander keuse gehad as om die Konsulentsgemeente van Pretoria se afgevaardigdes op te roep om deel te neem aan die konstituering van die Vergadering nie. Die Konsulentsgemeente het géén afgevaardigdes gestuur nie maar dit het nié aan ds H L Neethling, as voorsitter, die reg gegee om die Konsulentsgemeente se naam te verswyg nie. Daar was immers ánder Hervormde kerkrade wat formeel nié kon "verenig" met 'n Ned Gereformeerde kerkraad nie omdat daar géén Ned Gereformeerde gemeente in hulle distrik bestaan het nie, soos in Waterberg. 'n Ander kerkraad soos die van Zeerust het géén afgevaardigdes gestuur nie en tog is die gemeente se naam op die lys geplaas. ${ }^{27}$

Uit die handelinge van die verenigde Algemene Kerkvergadering word dit gou duidelik dat die voorsitter, ds $\mathrm{H}$ L Neethling, op eie gesag die naam van die Konsulentsgemeente weggelaat het. In sy toespraak oor hierdie aangeleentheid, het hy gesê: ${ }^{28}$

"zeggende, nadat hij Artikel 11 heeft voorgelezen, dat niemand beter dan hij de bedoeling van dit artikel kan uitleggen, omdat hij het zelf heeft opgesteld, met medeweten van al de afgevaardigden der Ned Gereformeerde Kerk, en de bedoeling is, dat het zal toegepast worden op al de gemeenten."

Dit mag waar wees dat ds Neethling die bedoeling van die artikel die beste kon verstaan het. Maar in sy argument maak hy twee foute. Ten eerste is dit so dat die bedoeling of betekenis van artikel XI, nadat dit 
geformuleer én aangeneem is, nié meer bepaal kan word deur die opvattings of mening van die opsteller daarvan nie maar uitsluitlik deur die woorde van die artikel sélf. Daarom was die relaas van sy bedoelings eintlik nie meer ter sake nie. As daar dan verder gelet word op die inhoud van artikel XI dan is dit duidelik dat dit, binne sy konteks, alléén betrekking kan hê op die vereniging van kerkrade van Ned Hervormde met Ned Gereformeerde gemeentes. Nêrens in die corpus van dáárdie reeks reëlings word die indruk geskep óf die bedoeling gestel dat dit óók van toepassing is op 'n vereniging van twee Hervormde gemeentes nie. Die Kommissie van die Ned Hervormde Algemene Kerkvergadering het in September 1885 die korrekte uitleg gegee van artikel XI en ds $\mathrm{N}$ J van Warmelo se argument op die verenigde Algemene Kerkvergadering, was óók volkome korrek. Hy het gesê: ${ }^{29}$

“... en geeft te kennen, dat de Consulentsgemeente niet valt onder de termen van Artikel 11 der Commissiebesluiten, want dat er sprake was van vereeniging van twee Kerkgenootschappen, die Ned Hervormde en Ned Gereformeerde, en niet van vereeniging van Hervormd en Hervormd . .."

Ds Neethling, so moet uit sy gedrag en uitsprake afgelei word, wou nié die de facto bestaan van die Konsulentsgemeente erken nie en deur'n uitleg van artikel XI, wat foutief was, het hy'n Hervormde gemeente sy bestaansreg binne die verenigde kerk en die kerkraad se onbetwisbare sittingsreg op die verenigde Algemene Vergadering volkome willekeurig ontsê. ${ }^{30}$

Op grond van die foutiewe leiding wat ds Neethling, as voorsitter gegee het, besluit die verenigde Algemene Vergadering dat die Konsulentsgemeente binne die organisatoriese struktuur van die verenigde kerk ook de iure géén bestaansreg het nie want dié gemeente word versoek om met die gemeente Pretoria, onder die bediening van ds H S Bosman, saam te smelt. Al die Hervormde gemeentes wat in Desember 1885 de iure en de facto bestaan het, kon deel word van die verenigde kerk behalwe die Konsulentsgemeente van Pretoria want ds H L Neethling, gesteun deur 'n handige meerderheid op die Algemene Vergadering, wou dit nie so gehad het nie. Dit terwyl daardie eerste Vergadering van die verenigde kerk géén jurisdiksie of enige seggenskap, op daardie stadium, oor die de facto bestaan van 'n Hervormde gemeente gehad het nie. Die Vergadering self het dit onwetend erken as later oor "onafgedane zaken" gehandel moet word en besluit word om daar artikel XII van die Tweede Verenigingskomissierapport van 1885 te laat geld wat gelui het: ${ }^{31}$

"Deze vergadering is van oordeel, dat, zoolang de nieuwe wet voor de Ned Hervormde of Gereformeerde Kerk nog niet is 
vasgesteld, de wetten in gebruik zullen blijven bij de gemeenten waarbij zich de andere gemeente aansluit."

Hierdie reëling het die foutiewe van ds H L Neethling se optrede onderstreep want hiervolgens was die reël dat die Kerkwet en besluite van die Ned Hervormde Kerk van toepassing moet wees op die probleem van die bestaan van die Konsulentsgemeente. Maar die Hervormde Kerkwet, besluite en voortdurende gebruik het dan juis die de facto én die de iure besluit van die Konsulentsgemeente volledig erken!

As hierdie situasie so, vanuit die kerkregtelike hoek besien word, is dit duidelik dat ds H L Neethling ten opsigte van die Konsulentsgemeente die Algemene Vergadering van die verenigde kerk so gelei het dat ' $n$ growwe flater begaan is. Die besluit van die Vergadering ten opsigte van die Konsulentsgemeente was, in die lig van artikel $X I$, ultra vires. Omdat die Vergadering egter op die weg volhard het en sy besluit ten opsigte van die Konsulentsgemeente gehandhaaf het, het die Vergadering self afgewyk van die grondslae van die vereniging en sodoende ' $n$ groot vraagteken oor die regmatigheid van die vereniging getrek.

Veel word gemaak van die verenigde kerk se herhaalde versoeke aan die Konsulentsgemeente om tog maar, ook na die vergadering van 1885, die probleme te bespreek. Vir die Konsulentsgemeente was daar egter, ná die besluit van die vergadering, niks met die verenigde kerk te bespreke nie want die Algemene Vergadering het die de facto en de iure bestaan van die gemeente ten ene male ontken. Dit is merkwaardig dat die verenigde kerk wou bly onderhandel met 'n gemeente waarvan hy die bestaan nie erken het nie en aan wie hy bykomende vereistes gestel het om opgeneem te kan word in die organisatoriese struktuur van die verenigde kerk. Daarom klink die besluit van die verenigde kerk se Algemene Vergadering van 1888 ook na vrome huigelary.

Die Konsulentsgemeente het, ondanks die foutiewe en hooghartige optrede van ds H L Neethling, daarin gesteun deur'n handige meerderheid op sy Algemene Vergadering, deurentyd volkome korrek opgetree. Die ironie van die hele situasie het in 1893, met die uitspraak van die Hooggeregshof in die Trichardtfonteinse Kerksaak, mooi na vore gekom. Die Hooggeregshof het beslis dat die Kerkvereniging ultra vires en dus nietig was en dáármee is die de iure bestaan van die verenigde kerk vernietig. Dit was dus nié die Konsulentsgemeente van Pretoria wat géén bestaansreg gehad het nie maar wel die Algemene Vergadering van die sogenaamde verenigde kerk. Dit is egter selde in die Kerkgeskiedenis dat die magsmisbruik en flaters van 'n voorsitter só gou en só effektief gedemonstreer word.

As daar nou na die oorsake van die "skeuring" gevra word, dan is 
dit in hierdie konteks duidelik dat daar nie van "skeuring" sprake kan wees nie. Immers, volgens die Hooggeregshof-uitspraak het daar in 1885 géén wettige kerkvereniging plaasgevind nie. Wat wél plaasgevind het, was dat'n groot getal Hervormde lidmate die kerk verlaat het om saam met ander mense ' $n$ nuwe kerkgenootskap te vorm. Diegene wat nié verenig het nie, wat dus nié weggebreek het van die wettigbestaande Hervormde Kerk nie, het die Ned Hervormde Kerk soos dit nog altyd bestaan het, voortgesit. Met ander woorde die Konsulentsgemeente was juridies én moreel volkome korrek toe hulle in 1886 gestel het:

"Maakt geene objectie omtrent het niet opnemen dezer Gemeente in de rij der Gemeenten van die Ned Hervormde of Gereformeerde Kerk. Gevoelt ons integendeel tevreden te blijven het geen wij was en nu nog ben, namelijk Ned Herv."

As daar rondom 1885 van ' $n$ skeuring sprake is, dan lê die blaam op diegene wat weggeskeur het van die ou moederkerk om 'n nuwe kerklike organisasie op te rig. Baie van hulle het later, ontnugter deur die gang van sake, deur middel van die Prokurasie Kommissie teruggekeer na die Ned Hervormde Kerk. Dat dié skeuring, wat tot 'n groot disorganisasie in en van die Ned Hervormde Kerk gelei het, onder die naam van Kerkvereniging plaasgevind het, is één van die koddighede van ons geskiedenis.

Die gebeure van 1885 en 1886 en wat daarop gevolg het, het voorlopig die einde van die kerkverenigingsideaal beteken. In daardie krisisjare het die leidinggewende ouderlinge van die Konsulentsgemeente 'n sleutelrol gespeel. Omdat hulle optrede en die motiewe daarvan reeds elders behandel is, word nie weer hier daarna verwys nie. ${ }^{32}$

Een saak is egter wel duidelik uit die gebeure van 1885-1886 en dit is dat die etiket van "sondige verskeurdheid" in géén geval op die Konsulentsgemeente van toepassing is nie. Miskien kan die vraag liewer gestel word: Waarom het die seën van die Here nie op die kerkvereniging gerus nie? Waarom het die kerkvereniging tot groter tweespalt en twis as ooit tevore aanleiding gegee? Was dit nie dalk omdat die kerkvereniging beplan en deurgevoer is met die doel om die ou moederkerk, die Ned Hervormde Kerk te vernietig nie? Was die doel nie dalk méér kerklike imperialisme, wat hand aan hand met die staatkundig-kulturele imperialisme van Engeland gegaan het as 'n werklik diep-Christelike en gelowige poging om op kerklike vlak bymekaar te bring wat by mekaar gehoort het nie?

Dit is nogal opvallend dat die beskuldiging van "sondige verskeurdheid" óf direk óf implisiet nogal graag deur die eenheidsmakers voor die deur van die Ned Hervormde Kerk gelê word. Tiperend van dié soort beskuldiging is onder andere 'n opmerking van ds $\mathrm{H} \mathrm{S}$ Bosman uit 1923 waar hy sê: ${ }^{33}$ 
"Die eerste Hervormde Kerk in die Transvaal droeg van 1858 tot 1885 een Kerkelijke onwettige naam zooals hierboven aangetoond en men vergewe mij wat ik nu ga zeggen (het doet mij pijn om dit te zeggen, maar gezegd worden moet het ter wille van de waarheid) de tweede Hervormde Kerk van 1889 tot nu is een Scheur Kerk. De pauselijke prokuratie Commissie beheerd door ouderling W, (= A D W Wolmarans) die kennis gaf aan predikanten en Kerkeraadsleden dat zij niet meer in dienst der Kerk waren en Kerkelijke goederen met geweld in bezit nam, gaf aanleiding tot die scheuring. Ter wille van een naam die onwettiglijk aan de Kerk gegeven werd zoowel in Holland in 1816 als in de Transvaal "bij toeval" in 1858 heeft die onnodige en pijnlijke scheuring van 1890 haar oorsprong te danken."

Dit is so ' $n$ eienaardige reeks stellings dat enige objektiewe historikus homself moet afvra of hierdie dominee inderdaad ' $n$ oogen oorgetuie was van dié dinge waaroor hy skrywe. Waarheid, verbeelding en willekeurige voorstellings van feite laat hierdie dominee inderdaad vér van die werklikheid beland en tog word sy eienaardige opvattings tot vandag toe nog as "gesaghebbend" beskou. Tog is dit tipies van die hooghartige, voortvarende houding wat deur die jare aan die dag gelê is deur die eenheid-skreeuers wat die kerklike verlede nie ken nie of nié daarop let nie. Daarom is dit nie so merkwaardig dat die geroep om "kerklike eenwording" met 'n groot mate van terughoudendheid deur baie in die Ned Hervormde Kerk bejeën word nie.

Indien die kerklike geskiedenis nagegaan word, dan blyk dit wel dat die etiket van "onwettig" of "skeurkerk" wat so graag en so maklik aan die Ned Hervormde Kerk gehang word, nié daar tuishoort nie. Veel eerder moet daar groot én ernstige kerkregtelike vraagtekens geplaas word agter die bestaansreg van die kerk wat ds $F$ L Cachet in die ou ZAR kom stig het. Dáárdie kerkstigting wat inderdaad 'n kerkskeuring was, is nié deur die sogenaamde kerkvereniging van 1885 , gewettig nie veral omdat die kerkvereniging in 1893 deur die Hooggeregshof as ultra vires bestempel is.

Dit is miskien tog belangrik om in hierdie dae, waar daar so baie oor organisatoriese kerklike eenheid gepraat word, wéér die stelling van ds $\mathrm{N} J$ van Warmelo te herhaal. Hierdie man wat deur ds Bosman as "edel en eerlijk" bestempel word, het tydens die Algemene Kerkvergaderng van die Ned Hervormde Kerk in 1879, toe die saak van kerkvereniging bespreek is, voorgestel: ${ }^{34}$

"De Algemene Kerkvergadering zet de deuren der Kerk wijd open voor elkeen die in de Hervormde Kerk wil inkomen." 
Elkeen wat vandag nog in leer, belydenis en lewenswandel trou is aan die Formuliere van Enigheid, is as lidmaat welkom in die Ned Hervormde Kerk, die Kerk van die Voortrekkers, die "moederkerk" in Transvaal. So 'n standpunt lyk, vanuit die geskiedenis gesproke, méér verantwoordbaar as baie van die "eenheidsargumente" wat vandag gehoor word.

1 Vergelyk o a F A F Wichmann, Die Wordingsgeskiedenis van die Zuid-Afrikaansche Republiek 1838-1860, Kaapstad 1941 asook A N Pelzer, Wordingsjare, Kaapstad-Amsterdam 1950.

2 Sien o a F A van Jaarsveld, Die Ontwaking van die Afrikaner Nasionale Bewussyn, Johannesburg, 1957.

3 Vergelyk o a De Volksstem, 5101881 waar verslag gedoen is van 'n openbare vergadering te Pretoria wat oor 'n moontlike Kerkvereniging gehandel het en toegespreek is deur die Driemanskap vise-president S J P Kruger, oud-president $M$ W Pretorius en Komdt-genl P J Joubert.

4 Notulen der Algemeene Kerkvergadering 1879, bladsy 15.

5 A D Pont, Nicolaas Jacobus van Warmelo 1835-1892, Utrecht 1955, bladsy 135.

6 Notulen van de zitting der Vereenigde Commissien van de Ned Heroormde en Ned Gereformeerde Kerken in de Z A Republiek, inzake Kerkvereeniging, gehouden te Pretoria, op Dinsdag, 31 October 1882, des namiddags ten 4 ure, en volgende dagen, in het Kerkgebouw der Hervormden te Pretoria, Pretoria, z j, bladsy 4 asook bladsy 55-60. Sien ook De Volksstem, 21 Desember 1881.

7 Vergelyk A D Pont, $a w$, bladsy $136 \mathrm{vg}$.

8 Dit is nie nodig om hier weer uitvoerig op hierdie punte in te gaan nie omdat dit al meerdere male beskryf is. Vergelyk in hierdie verband o a A D Pont, $a w$, bladsy 138-139 e a, S P Engelbrecht, Geskiedenis van die Nederduitsch Heroormde Kerk van Afrika, Pretoria-Kaapstad 1953, bladsy 285 vg en ook G D Scholtz, Die Geskiedenis van die Nederduitse Hervormde of Gereformeerde Kerk van Suid-Afrika, 1842-1885, Kaapstad - Pretoria 1956, bladsy 278 vg.

9 Die punt het veral na vore gekom toe gehandel is oor die vraag wáár die aankomende predikante vir die toekomstige verenigde kerk gelegitimeer sou moes word. Die beslissing dat dit aan die Kaap by ' $n$ "buitelandse kerk" moet geskied het organisatories-struktureel beteken dat die verenigde kerk in die ZAR hom in 'n onderhorige posisie ten opsigte van die Kaapse Ned Gereformeerde Kerk geplaas het. Daarmee is van die Ned Hervormde Kerk gevra dat hy in die verenigde kerk sy 1853-standpunt sou moes prysgee tesame met sy organisatoriese onafhanklikheid. Dit sou óók beteken dat die staatkundig-kulturele beleid van die Kaapse kerk soos onder andere weerspieël deur die Herderlike Skrywe van 1837 teen die Groot Trek, nou 'n maklike invalspoort in die verenigde kerk gegee is.

10 Notulen de Vereenigde Commissien, bladsy 61 Volgens die Notulen der Algemeene Vergadering, 1882, bladsy 5 het die Hervormde Kommissie, om konsensus te kan bereik, toegewings gemaak ten opsigte van die proponentsondertekeningsformule, die legitimasie van aankomende predikante, en die naam van die Kerk. Dit is tereg as "groote veranderingen" aangedui.

11 Notulen der Algemeene Kerkvergadering, 1882, bladsy 4.

12 Ouderling M J Prinsloo en ouderling C J J Joubert van die Konsulentsgemeente Pretoria het hulle teenstemme laat aanteken omdat hulle gevoel het dat die verenigingsvoorstel téén die belange van die gemeente indruis. Hierdie twee ouderlinge word die rots waarop die skip van die verenigde kerk gestrand het.

13 Vergelyk A D Pont, $a$ w, bladsy $149 \mathrm{v}$.

14 Ds N J van Warmelo se toespraak op die Algemene Kerkvergadering van 1884 het baie duidelik dié argument genoem vergelyk Notulen, bladsy 32-35. Ná die vereniging van 1885 het dit binne die verenigde kerk baie sterk na vore gekom. Vanweë die feit dat die Ned Hervormde Kerk op daardie stadium grotendeels bedien is deur predikante wat hulle opleiding te Stellenbosch ontvang het, was daar aanvanklik weinig verset téén die kapitulasie van die Ned Hervormde Kerk. 
Dit is wel interessant om te sien hoe hierdie corgawe van die Ned Hervormde Kerk sorgvuldig beplan is en nog sorgvuldiger vermom is want die gewone kerkraadsen gemeentelid is wysgemaak dat die toegewings wat hulle moet maak om die hoe ideaal van vereniging te bereik, eintlik niksbeduidend was. Die feit is dat die Ned Hervormde Kerk enorme toegewings gemaak het op punte waar, onder ander omstandighede, geen toegewing ooit verwag kon word nie. Die algemene klimaat was egter van so' $n$ aard dat ' $n$ teenwerking van die verenigingsideaal werklik as 'n soort "verraad" bestempel kon word. In later jare het ds H S Bosman selfs die Kerkvereniging probeer korreleer met die belofte en die klipstapeling te Paardekraal in 1880 !

15 Vergelyk A D Pont, $a$ w, bladsy 147-159.

16 A D Pont, $a w$, bladsy 158.

17 G B A Gerdener, Boustowwe vir die Geskiedenis van die Nederduits-Gereformeerde Kerk in die Transgariep, Kaapstad 1930, bladsy 402. Dit vorm deel van die Notule van die Ned Hervormde Kerk se Algemene Vergadering van Januarie 1885.

18 Vergelyk S P Engelbrecht, a $w$, bladsy 251-252.

19 H S Bosman, Een terugblik op kerkelijke en Godsdienstige toestanden in de Transvaal, Kaapstad 1923, bladsy $67-68$ is van mening dat die gemeente se bestaan "onwettig" was en stel dat die gemeente se bestaan onwettig was en stel dat die "onwettige wordt het fondament om op te bouwen, wat al meer malen gebeurd is in de geschiedenis van de Hervormde Kerk." Dit is 'n interessante standpunt wat Bosman hier inneem. Dit korreleer egter nié met sy optrede as predikant in die Ned Hervormde Kerk toe hy nooit enige besware teen of die de facto of de iure bestaan van die Konsulentsgemeente gehad het nie.

20 A D Pont, $a w$, bladsy 159.

21 G B A Gerdener, $a w$, bladsy 423

22 G B A Gerdener, $a w$, bladsy 425 . My beklemtoning.

23 Aangehaal by S P Engelbrecht, $a$ w, bladsy 306. My beklemtoning.

24 Aangehaal by S P Engelbrecht, $a w$, bladsy 307.

25 Aangehaal by S P Engelbrecht, $a w$, bladsy 316.

26 Aangehaal by G D Scholtz, $a w$, Dl2, bladsy 14.

27 G B A Gerdener, $a w$, bladsy 424 .

28 G B A Gerdener, $a w$, bladsy 425.

29 G B A Gerdener, $a w$, bladsy 424

30 As H S Bosman, a w, bladsy 69-70 nagegaan word, dan word dit wél duidelik wáárom ds Neethling so opgetree het. In die kringe van die Stellenbosse predikante is skynbaar die ideaal gestel om met die kerkvereniging sommer ook die sake van die "onwettige" Ned Hervormde Kerk "reg te maak." Bosman stel in hierdie verband: "Hoe is nu zijn (d i ds G W Smits, die konsulent van die Konsulentsgemeente) weigering te verkalren om in termen van Artikel XI - ook door zijn toedoen opgesteld en ondertekend - om zijn Consulentsgemeente, die van Witfontein, namelijk in een te doen smelten met die van Pretoria, iets dat hij in 1882 en 1884 "zeer wenschelijk" achte? Maar neen waar het begin en de voortgang van een zaak onwettig is, daar volgt men nog alte graag die onwettige weg verder totdat die doodloopt, zooals met Witfontein gebeurd is in 1904, bij de ineensmelting met de Procuratie Commissie gemeente, en zoo is het onwettige Witfontein geworden het fondament en aanknopingspunt van en voor de tegenwoordige Hervormde Kerk en zooals hierboven gebleken is het fondament van Witfontein Kerkelijk onwettig geweest; en dus ook het gebouw daarop!"' Uit hierdie stellings blyk wel dat Bosman nooit verstaan het wat die Hofuitspraak in die Trichardtfonteinse Kerksaak van 1893 beteken het nie.

31 G B A Gerdener, $a w$, bladsy 402.

32 A D Pont, $a w$, bladsy $160 \mathrm{vg}$.

33 H S Bosman, $a$ w, bladsy 70 .

34 A D Pont, $a w$, bladsy 126. 